\title{
IDENTIFIKASI BAKTERI PADA IKAN AIR LAUT DI BALAI KARANTINA IKAN PENGENDALIAN MUTU DAN KEAMANAN HASIL PERIKANAN KELAS I NGURAH RAI DENPASAR, BALI
}

\author{
Identification Of Bacteria on Marine Fish at Fish Quarantine and Inspection Agency \\ Class I Ngurah Rai Denpasar, Bali
}

\author{
Seto Sugianto P.R. ${ }^{1}$, Ifatul Masfiah ${ }^{1 *}$, Indirawati Fairwandari ${ }^{2}$ dan Sulis Nur Hidayati ${ }^{2}$ \\ ${ }^{1}$ Budidaya Perairan, Fakultas Perikanan dan Ilmu Kelautan Universitas Brawijaya, Malang \\ ${ }^{2}$ Karantina Ikan Pengendalian Mutu dan Penyakit Ikan Kelas I Denpasar \\ *masfiah.ifa@gmail.com
}

\begin{abstract}
Abstrak
Potensi terbesar yang dimiliki Indonesia dari sektor non migas salah satunya adalah pengembangan sumber daya perairan. Indonesia yang sekitar 75\% wilayah teritorialnya merupakan perairan dengan berbagai kekayaan yang sudah maupun belum dikelola dengan optimal. Kegiatan Perikanan memiliki peranan besar terhadap perekonomian bangsa dan Negara. Keberadaan penyakit di perairan merupakan salah satu kendala dalam pengembangan subsektor budidaya perikanan. Tujuan dari identifikasi bakteri pada ikan air laut adalah untuk mengetahui jenis bakteri yang dapat menginfeksi dan menyebabkan penyakit pada ikan air laut. Selain itu juga untuk menambah keterampilan dan pengetahuan. Penelitian dilaksanakan pada tanggal 10 Juli sampai dengan 25 Agustus 2017 di Balai Karantina Ikan Pengendalian Mutu dan Penyakit Ikan Kelas I Denpasar, Bali. Pengambilan data dilakukan dengan cara observasi lapang, wawancara dan partisipasi aktif. Teknik identifikasi bakteri menggunakan metode konvensional dengan menggunakan uji biokimia. Uji Biokimia adalah suatu cara untuk mengidentifikasi bakteri melalui sifat-sifat fisiologinya. Identifikasi bakteri selama penelitian hanya dilakukan pada ikan hias air laut. Dari 43 ikan hias yang diidentifikasi selama pada proses identifikasi diperoleh 2 jenis bakteri yaitu bakteri Vibrio parahaemolyticus dan Vibrio vulnificus.
\end{abstract}

Kata Kunci: Uji Biokimia, Vibrio parahaemolyticus, Vibrio vulnificus

\begin{abstract}
The biggest potential of Indonesia from the non-oil sector is one of them is the development of water resources. Indonesia which is about $75 \%$ of territorial territory is a waters with various wealth that has or has not been managed optimally. Fisheries activities have a great role to the economy of the nation and the State. The existence of disease in the aquatic environment is one of the constraints in the development of fishery aquaculture sub-sector. The purpose of identification of bacteria in sea water fish is to know the type of bacteria that can infect and cause disease in sea water fish. In addition, to increase skills and knowledge. The research was conducted on July 10 until August 25, 2017 at Fish Quarantine and Inspection Agency Class I Denpasar, Bali. Data were collected by means of field observation, interviews and active participation. Mechanical identification of bacteria using a conventional method using a biochemical test. Biochemical testing is a way to identify bacteria through its physiological properties. Identification of bacteria during the study only carried on marine ornamental fish. For 43 fish that were identified during the identification process obtained two types of bacteria are bacteria Vibrio parahaemolyticus and Vibrio vulnificus.
\end{abstract}

Keyword: Biokimia Test, Vibrio parahaemolyticus, Vibrio vulnificus

\section{PENDAHULUAN}

Potensi terbesar yang dimiliki Indonesia dari sektor non migas salah satunya adalah pengembangan sumber daya perairan. Indonesia yang sekitar 75\% wilayah teritorialnya merupakan perairan dengan berbagai kekayaan yang sudah maupun belum dikelola dengan optimal. Berkaitan dengan potensi perairan, maka sektor perikanan dan kelautan adalah salah satu stakeholders yang bertanggung jawab di dalam pengelolaannya. Subsektor kelautan, perikanan tangkap, budidaya perairan tawar, laut, dan payau, pengolahan, hingga pemasaran memegang peranan penting di dalam siklus bioindustri perikanan dan kelautan, mulai dari hulu hingga hilir (Kurniawan, 2012). 
Keberadaan penyakit di dalam lingkungan perairan merupakan salah satu kendala di dalam pengembangan subsektor budidaya perikanan. Penyebab penyakit tersebut dapat berupa faktor fisika dan kimia lingkungan, pakan dan metabolisme, stress sebagai bagian reaksi psikologis ikan. Serangan penyakit tersebut dapat berakibat pada terganggunya produktivitas budidaya bahkan dapat menyebabkan kegagalan hingga menimbulkan kerugian (Handayani et al., 2015). Selain itu kenaikan atau penurunan suhu secara mendadak dapat menyebabkan stres pada ikan. Kepadatan ikan yang tinggi akan menyebabkan ikan mudah stress sehingga lebih mudah terserang penyakit. Kualitas air yang buruk, pemberian pakan ikan yang berlebih dan perubahan iklim merupakan faktor penyebab timbulnya penyakit (Azmi, et al., 2013).

Dengan adanya permasalahan tersebut, kegiatan penelitian ini penting dilakukan untuk mengetahui bakteri pada ikan air serta mendapatkan pengalaman dan keterampilan secara langsung Di Balai Karantina Ikan Pengendalian Mutu dan Keamanan Hasil Perikanan Kelas I Ngurah Rai Denpasar, Bali.

\section{METODOLOGI}

\section{Waktu dan Tempat}

Penelitian ini dilaksanakan mulai tanggal 10 Juli sampai dengan 25 Agustus 2016 di Balai Karantina Ikan Pengendalian Mutu dan Keamanan Hasil Perikanan Kelas I, Ngurah Rai, Denpasar, Bali.

\section{Materi Penelitian}

Peralatan Penelitian

Pada penelitian ini alat yang digunakan adalah sectio set, gelas ukur, Erlenmeyer, cawan petri, beaker glass, inkubator, kulkas, jarum ose, bunsen, autoclave, laminary, hot plate, spatula, magnetic stir, timbangan analitik dan korek api.

\section{Bahan Penelitian}

Pada penelitian ini bahan yang digunakan adalah ikan air laut yang berasal dari pembudidaya yang ada di pulau Bali. Media yang digunakan untuk isolasi bakteri adalah media TSA (Triptic Soy Agar) 3\% dan TCBS (Thiosulfate Citrate Bile Salts Sucrose Agar). Sedangkan bahan untuk uji biokimia adalah OF, Citrate, Potasium nitrat, Ornithin, Lysin, SIM (Sulfid Indol Motility), Indol, Gelatin, Urea, MRVP, TSIA (Triple Sugar Iron Agar), Gula-Gula dan Akuades.

\section{Prosedur Kerja}

Metode yang digunakan untuk Identifikasi Bakteri pada ikan air laut adalah metode konvensional dengan Uji Biokimia. Uji Biokimia adalah suatu cara untuk mengidentifikasi bakteri melalui sifat-sifat fisiologinya. Pada Uji Biokimia menggunakan beberapa media diantaranya media Karbohidrat, OF, Citrat, Nitrat, Ornithin, Lysin, SIM Motility, Indol, Gelatin, Urea, MRVP, TSIA dan TCBS. Adapun langkah-langkah identifikasi bakteri yaitu pertama dilakukan isolasi dengan organ target yaitu insang, kemudian dilakukan diinkubasi selama 24 jam dengan suhu $28^{\circ} \mathrm{C}$. Kemudian dilakukan pemurnian dengan menggunakan media TSA 3\% dan diinkubasi selama 24 jam dengan suhu $28^{\circ} \mathrm{C}$. Setelah itu dilakukan Uji Biokimia dan diinkubasi selama 24 jam dengan suhu $28^{\circ} \mathrm{C}$. Setelah 24 jam maka dilakukan pembacaan hasil uji biokimia dan hasil dari uji biokimia diidentifikasi dengan metode konvensional (Bacteriology John G. Holt et al. tahun 1994).

\section{HASIL DAN PEMBAHASAN}

Pada Penelitian di Laboratorium Mikrobiologi Balai Karantina Ikan Pengendalian Mutu dan Penyakit Ikan Kelas I Denpasar teknik identifikasi bakteri yang digunakan adalah metode konvensional dengan uji biokimia. Identifikasi bakteri selama Penelitian hanya dilakukan pada ikan hias air laut. 
Sebanyak 43 ikan hias yang diidentifikasi selama pengamatan. Jenis-jenis ikan yang diidentifikasi disajikan pada lampiran. Pada proses identifikasi diperoleh 2 jenis bakteri yaitu bakteri Vibrio parahaemolyticus dan Vibrio vulnificus. Vibrio parahaemolyticus ditemukan pada ikan dengan kode sampel BIH8, sedangkan Vibrio vulnificus ditemukan pada ikan dengan kode sampel BSF7, BAR7, ST7, AAM7, NSR7, BS8, NAM8, BAA8. Hasil uji biokimia disajikan pada lampiran.

Bakteri yang telah teridentifikasi pada sampel dengan menggunakan metode uji Biokimia yang dilakukan selama pengamatan di Laboratorium Mikrobiologi Balai Karantina Ikan Pengendalian Mutu dan Penyakit Ikan (BKIPM) Kelas I Denpasar adalah Vibrio vulnificus dan Vibrio parahaemolyticus.

\section{Vibrio vulnificus}

Bakteri Vibrio vulnificus yang ditemukan di Laboratorium Mikrologi Balai Karantina Ikan Pengendalian Mutu dan Penyakit Ikan (BKIPM) Kelas I Denpasar terdapat pada sampel isolat dengan kode BSF7, BAR7, ST7, AAM7, NSR7, BS8, NAM8, BAA8. Menurut Tae Hee Lee et al. (2011), Vibrio vulnificus adalah bakteri Gram-negatif halofilik yang secara alami hidup di daerah estuari dengan salinitas air dan suhu yang bervariasi. Bakteri Vibrio vulnificus adalah bakteri yang menyebabka sebagian besar kasus kematian organism laut dan jumlah infeksi Vibrio vulnificus telah meningkat karena adanya perubahan iklim global. Sebagian besar infeksi Vibrio vulnificus terjadi ketika suhu air lebih tinggi dari $20^{\circ} \mathrm{C}$ selama musim panas. Menurut Rengpipat et al. (2008), Vibrio vulnificus ( $\gamma$-Proteobacterium termasuk dalam Famili Vibrionaceae) adalah spesies bakteri Gram-negatif yang dapat ditemukan di perairan payau dan hangat. Vibrio vulnificus berbentuk batang motil melengkung dan memiliki flagelum polar bermotif tunggal. Spesies ini juga memiliki beragam gaya hidup, ada yang ditemukan sebagai bakteri hidup bebas di laut dan sebagai parasit hewan seperti moluska, ikan, crustasea dan mamalia (termasuk manusia). Strain Vibrio vulnificus memiliki potensi patogen untuk manusia dan hewan air, seperti udang dan belut.

\section{Vibrio parahaemolyticus}

yang ditemukan di Laboratorium Mikrologi Balai Karantina Ikan Pengendalian Mutu dan Penyakit Ikan (BKIPM) Kelas I Denpasar terdapat pada sampel isolat dengan nomor kode BIH8. Menurut Chang-ho kang (2017), Vibrio parahaemolyticus adalah bakteri gram negatif dan halofilik yang ada secara alami di lingkungan laut dan seringkali terisolasi dari makanan laut. Menurut Stallin and Srinivasan (2016), Vibrio parahaemolyticus merupakan mikroorganisme laut yang berasal dari air muara. Vibrio parahaemolyticus memiliki toleransi terhadap suhu tinggi, $\mathrm{pH}$ dan salinitas. Bakteri ini sebagian besar bersifat patogen dan menyebabkan Early Mortality Syndrome (EMS) pada tambak udang. Vibrio parahaemolyticus menyebabkan kerusakan akut pada organ hepatopancreas, menyerang perut udang, dan melepaskan toksin pada industri akuakultur.

\section{KESIMPULAN DAN SARAN Kesimpulan}

Berdasarkan hasil penelitian mengenai identifikasi bakteri pada ikan air laut dapat disimpulkan bahwa Pada Penelitian bakteri yang diperoleh dengan menggunkan metode uji biokimia adalah Vibrio parahaemolyticu dan Vibrio vulnificus. Proses identifikasi bakteri meliputi proses isolasi, pemurnian, uji biokimia dan identifikasi. Buku yang digunakan di balai Karantina Ikan Pengendalian Mutu dan Penyakit Ikan untuk identifikasi bakteri adalah buku Bergey's Manual of Determinative Bacteriology karangan John G. Holt et al. 
tahun 1994 Pada proses pemeriksaan bakteri di balai Karantina Ikan Pengendalian Mutu dan Penyakit Ikan hanya dilakukan pada sampel ikan hias saja. Kemudian teknik yang digunakan dalam identifikasi bakteri adalah metode uji biokimia. Media uji biokimia yang digunakan adalah media OF, Nitrat, Citrat, MIO (Ornithin), Lysin, SIM Motility, Indol, Gelatin, Urea, MRVP, TSIA dan Karbohidrat.

\section{Saran}

Sebaiknya dilakukan penelitian lanjutan dengan menggunakan metode PCR (Polymerase Chain Reaction) sehingga tingkat kepercayaan hasil penelitian dapat meningkat.

\section{DAFTAR PUSTAKA}

Afrianto, E., E. Liviawaty, Z. Jamaris dan Handi. 2015. Penyakit Ikan. Niaga Swadaya. Jakarta. $220 \mathrm{hlm}$.

Alamanda, I. E., N. S. Handajani dan A. Budiharjo. 2007. Penggunaan metode hematologi dan pengamatan endoparasit darah untuk penetapan kesehatan ikan lele dumbo (Clarias gariepinus) di kolam budidaya desa Mangkubumen Boyolali. Biodiversitas. 8 (1): 34-38.

Anshari, Z. 2011. Strategi pengembangan usaha pembesaran Ikan lele (Clarias sp) CV Jumbo Bintang Lestari di Gunung Sindur Kabupaten Bogor. Departemen Agribisnis Fakultas Ekonomi Dan Manajemen Institut Pertanian Bogor. Bogor.(tidak diterbitkan).

Azmi, H. D. R. Indriyanti dan N. Kariada. 2013. Identifikasi ektoparasit pada ikan koi (Cyprinus carpio L) di pasar ikan hias Jurnatan Semarang. Unnes J Life Sci. 2 (2): 64-70.

Bakhtiar, R. Z. S. Riyadi dan Asroni. 2015. Implementasi arsitektur operational data store (ods) dan dimensional data store (dds) dalam pembangunan data mart lulusan.
Jurnal Ilmiah Semesta Teknika. 18 (1): 55-64.

Bijanti, R., M. G. A. Yuliani dan W. Tyasningsih. 2011. Antigenesity protein of Aeromonas hydrophila caused ulcer disease on Goldfish (Cyprinus carpio linn) using indirect ELISA technique. Asosiasi Farmakologi dan Farmasi Veteriner Indonesia. 1-6.

Chang-Ho Kang, YuJin Shin, SeokCheol Jang, HongSik Yu, SuKyung Kim, Sera An, Kunbawui Park and JaeSeong So. 2017. Characterization of Vibrio parahaemolyticus isolated from oysters in Korea: Resistance to various antibiotics and prevalence of virulence genes. Marine Pollution Bulletin. 3-6.

Djaali, H dan P. Muljono. 2007. Pengukuran dalam Bidang Pendidikan. Grasindo. Jakarta. 144 hlm.

Dwiyitno. 2010 Identifikasi bakteri patogen pada produk perikanan dengan teknik molekuler. Squalen. 5 (2): 67-78.

Gani, I dan S. Amalia. 2015. Alat Analisis Data. ANDI, Anggota IKAPI. Yogyakarta.

Hamdi dan A. Saepul. 2014. Metode Penelitian Kuantitatif Aplikasi dalam Pendidikan. Deepublish. Yogyakarta. $171 \mathrm{hlm}$.

Handayani, M., D. Suryanto, T. Siregar dan Z. Efendi. 2015. Aktivitas antimikroba ekstrak kulit buah manggis (Garcinia mangostana) terhadap bakteri Aeromonas hydrophila, Edwardsiella tarda dan jamur Saprolegnia sp.

Hidayat, H. 2015. Pengolaan Hutan Lestari: Partisipasi, Kolaborasi dan Konflik. Yayasan Pustaka Obor Indonesia. Jakarta. 326 hlm.

Kordi, M.G. H dan A. Tamsil. 2010. Pembenihan Ikan Laut Ekonomis Secara Buatan. Lily Publisher. Yogyakarta. 191 hlm. 
Kordi, M.G. H. 2010. Panduan Lengkap Memelihara Ikan Air Tawar di Kolam Terpal. Lily Publisher. Yogyakarta. $103 \mathrm{hlm}$.

Kuncoro, E. B. 2004. Akuarium Laut. Kanisius. Yogyakarta. $229 \mathrm{hlm}$.

Kurniawan, A. 2012. Penyaakit Akuatik. UBB Press. Bangka Belitung. 239 hlm.

Puspowardoyo, H dan A. S. DJArijah. 1992. Membudidayakan Gurami Secara Intensif. Penerbit Kanisius. Yogyakarta.

Rahmaningsih, S. 2016. Hama dan Penyakit Ikan. Deepublish. Yogyakarta. 352 hlm.

Rengpipat, S., S. Pusiririt and S. Rukpratanporn. Differentiating between isolates of Vibrio vulnificus with monoclonal antibodies. Journal of Microbiological Methods. 398-404.

Rosidah dan W. M. Afizia. 2012. Potensi ekstrak daun jambu biji sebagai antibacterial Untuk menanggulangi serangan bakteri aeromonas hydrophila Pada ikan gurame (Osphronemus Gouramy lacepede). Jurnal Akuatika. 3 (1): 19-27.

Stalin, N and P. Srinivasan. 2016. Characterization of Vibrio parahaemolyticus and its specific phage from shrimp pond in Palk Strait, South East coast of India. Biologicals. 1-8.

Suwahyono, U. 2009. Cara Membuat dan Petunjuk Penggunaan Biopestisida. Penebar Swadaya. Jakarta. 165 hlm.

Tae Hee Lee, Young Ran Kim, Joon Haeng Rhee, Jin-Hong Kim, Hye Ryun Woo and Kyung Min Chung. 2011. Characterization of monoclonal antibodies targeting the RtxA1 toxin of Vibrio vulnificus. Process Biochemistry. 1500-1508.

Yudiarosa, I. 2009. Analisis ekspor ikan tuna indonesia. Wacana. 2 (1):116134.
Yuwono, T. 2009. Biologi Molekular. Erlangga. Jakarta. 269 hlm. 


\section{Lampiran}

Tabel I. Hasil identifikasi bakteri pada ikan air laut

\begin{tabular}{|c|c|c|c|c|c|c|c|}
\hline \multirow[b]{2}{*}{ Tanggal } & \multirow{2}{*}{$\begin{array}{c}\text { Kode } \\
\text { Sampel }\end{array}$} & \multirow[b]{2}{*}{ Nama Ikan } & \multicolumn{2}{|c|}{ Ukuran } & \multirow[b]{2}{*}{ Gejala Klinis } & \multirow{2}{*}{$\begin{array}{l}\text { Organ } \\
\text { Target }\end{array}$} & \multirow{2}{*}{$\begin{array}{c}\text { Hasil } \\
\text { Pemeriksaan }\end{array}$} \\
\hline & & & Panjang & Berat & & & \\
\hline $11-07-2017$ & BAQ7 & Chromis viridis & 5 & 1.8 & Normal & Insang & Negatif \\
\hline $11-07-2017$ & DAVA7 & Dascyllus aruanus & 4.5 & 1.7 & $\begin{array}{l}\text { Sirip Ekor } \\
\text { Geripis }\end{array}$ & Insang & Negatif \\
\hline $11-07-2017$ & LSR7 & Amphiprion ocellaris & 4 & 1.6 & Normal & Insang & Negatif \\
\hline $13-07-2017$ & BSF7 & Pseudochromis sp. & 6.4 & 3.9 & Normal & Insang & Vibrio Vulnificus \\
\hline $13-07-2017$ & BAR7 & Amphiprion ocellaris & 2.5 & 0.9 & Normal & Insang & Vibrio Vulnificus \\
\hline $24-07-2017$ & ST7 & Pomacentrus sp. & 3.9 & 2.1 & Normal & Insang & Vibrio Vulnificus \\
\hline $24-07-2017$ & DP7 & Chromis viridis & 3 & 1.2 & Normal & Insang & Negatif \\
\hline $25-07-2017$ & BC7 & Chaetodon sp. & 7 & 14 & Hati Pucat & Insang & Negatif \\
\hline $27-07-2017$ & PNJ7 & Chaetodon sp. & 8.1 & 14.5 & Normal & Insang & Negatif \\
\hline $28-07-2017$ & AAM7 & Pomacentrus sp. & 4.5 & 1.5 & Normal & Insang & Negatif \\
\hline $28-07-2017$ & AAM7 & Pomacentrus sp. & 4.2 & 1.5 & Normal & Insang & Vibrio Vulnificus \\
\hline $28-07-2017$ & CI7 & Dascyllus aruanus & 6.2 & 6.5 & Normal & Insang & Negatif \\
\hline $31-07-2017$ & NSR7 & Chrysiptera parasema & 4.5 & 1.5 & $\begin{array}{l}\text { Sirip Ekor } \\
\text { Geripis }\end{array}$ & Insang & Vibrio Vulnificus \\
\hline $01-08-2017$ & SSW8 & Dascyllus aruanus & 4.6 & 3 & Normal & Insang & Negatif \\
\hline $01-08-2017$ & BS8 & $\begin{array}{l}\text { Dascyllus } \\
\text { trimaculatus }\end{array}$ & 2.5 & 0.5 & Normal & Insang & Vibrio Vulnificus \\
\hline $01-08-2017$ & NAM8 & $\begin{array}{l}\text { Dascyllus } \\
\text { trimaculatus }\end{array}$ & 5.3 & 5.5 & Normal & Insang & Vibrio Vulnificus \\
\hline $01-08-2017$ & BSA8 & Dascyllus aruanus & 2.5 & 0.5 & $\begin{array}{l}\text { Sirip Ekor } \\
\text { Geripis }\end{array}$ & Insang & Negatif \\
\hline $01-08-2017$ & CB8 & Chromis viridis & 6 & 3.5 & Normal & Insang & Vibrio Vulnificus \\
\hline $02-08-2017$ & BAA8 & Pomacentrus coelektis & 4.2 & 1.5 & Normal & Insang & Vibrio Vulnificus \\
\hline $02-08-2017$ & BIH8 & Chrysiptera parasema & 4.8 & 2 & Normal & Insang & $\begin{array}{c}\text { Vibrio } \\
\text { parahaemolyticus }\end{array}$ \\
\hline $02-08-2017$ & LAN8 & $\begin{array}{l}\text { Dascyllus } \\
\text { trimaculatus }\end{array}$ & 2.5 & 0.5 & Normal & Insang & Negatif \\
\hline $02-08-2017$ & PPS8 & Amphiprion ocellaris & 3.7 & 1 & Normal & Insang & Negatif \\
\hline $08-08-2017$ & BAQ8 & Chromis viridis & 4.5 & 1.5 & Normal & Insang & Vibrio Vulnificus \\
\hline $08-08-2017$ & DAVA8 & $\begin{array}{l}\text { Dascyllus } \\
\text { trimaculatus }\end{array}$ & 2.4 & 0.5 & Normal & Insang & Negatif \\
\hline $08-08-2017$ & LSR8 & Pomacentrus coelektis & 4 & 1 & Normal & Insang & Vibrio Vulnificus \\
\hline $08-08-2017$ & ST8 & Dascyllus melanurus & 3.5 & 1.5 & Normal & Insang & Negatif \\
\hline $09-08-2017$ & BS8 & Stagestes sp. & 6.2 & 3.5 & Normal & Insang & Negatif \\
\hline $09-08-2017$ & BSA8 & Stagestes sp. & 6 & 2.6 & Normal & Insang & Negatif \\
\hline $09-08-2017$ & BSF8 & Plesiops sp. & 6 & 5.5 & Normal & Insang & Negatif \\
\hline $10-08-2017$ & $\mathrm{BBI} 8$ & Stagestes sp. & 5 & 2 & Normal & Insang & Negatif \\
\hline $10-08-2017$ & TSA8 & Chrysiptera parasema & 4.5 & 1.5 & Normal & Insang & Negatif \\
\hline $10-08-2017$ & BDC8 & Chaetodon sp. & 5.2 & 4.5 & Normal & Insang & Negatif \\
\hline $11-08-2017$ & ALB8 & Chromis viridis & 5.2 & 2.5 & Normal & Insang & Negatif \\
\hline $11-08-2017$ & BSM8 & Pomacentrus coelektis & 4.6 & 1.5 & Normal & Insang & Negatif \\
\hline $11-08-2017$ & DINAR8 & Chrysiptera parasema & 4.2 & 1.5 & Normal & Insang & Negatif \\
\hline $14-08-2017$ & DP8 & Pseudantias sp. & 4.8 & 1.5 & Normal & Insang & Negatif \\
\hline $14-08-2017$ & AAM8 & Pseudantias sp. & 4.2 & 1 & Normal & Insang & Negatif \\
\hline $14-08-2017$ & IP38 & Chrysiptera parasema & 3.3 & 1 & Normal & Insang & Negatif \\
\hline $14-08-2017$ & DEM8 & Chromis viridis & 6 & 3.5 & Normal & Insang & Negatif \\
\hline $15-08-2017$ & DINAR8 & $\begin{array}{l}\text { Dascyllus } \\
\text { trimaculatus }\end{array}$ & 4 & 2 & Normal & Insang & Negatif \\
\hline $22-08-2017$ & ALB8 & Dascyllus melanurus & 5 & 4 & Normal & Insang & Negatif \\
\hline $22-08-2017$ & MDS8 & Chromis viridis & 3 & 0.5 & Normal & Insang & Negatif \\
\hline $22-08-2017$ & AFB8 & Chromis viridis & 4.9 & 2 & Normal & Insang & Negatif \\
\hline
\end{tabular}

